\title{
M. tuberculosis Peptide based Point-of care test for TB
}

\author{
Jesus M Gonzalez ${ }^{1,2}$, Bryan Francis ${ }^{1}$, Sherri T Burda ${ }^{3}$, R Sam Niedbala ${ }^{1,2}$, Suman Laal ${ }^{1,3,4^{*}}$ \\ From 2nd International Science Symposium on HIV and Infectious Diseases (HIV SCIENCE 2014) \\ Chennai, India. 30 January - 1 February 2014
}

\section{Background}

A rapid, simple and affordable point-of care (POC) test that can be implemented in peripheral health care settings to replace/improve upon microscopy for $\mathrm{TB}$ diagnosis or to rule out $\mathrm{TB}$ (triage) remains unmet.

\section{Methods}

Immunodominant regions of 3 Mycobacterium tuberculosis specific cell-wall proteins that are highly immunogenic in HIV - TB+ and HIV+TB+ patients have been mapped. Antibodies to these regions are absent in subjects with latent $\mathrm{TB}, \mathrm{BCG}$ vaccination, other pulmonary diseases. To examine the feasibility of devising a peptide based rapid POC test, selected peptides were conjugated to a carrier protein using standard EDC/NHS coupling chemistry, purified by size exclusion; the peptide conjugation confirmed using MALDI MSMS before adsorption onto colloidal gold and striping onto nitrocellulose. The assay parameters were adjusted to determine positive/negative status within 15 minutes via visual or instrumented assessment.

\section{Results}

The prototype POC test was evaluated with sera from $\sim 400 \mathrm{~TB}$ patients, non TB subjects from the groups defined in the methods section. The current prototype POC test provides $>90 \%$ sensitivity and specificity in the above populations.

\section{Conclusion}

WHO recommends against use of all current commercial serological TB tests since they fail to achieve adequate sensitivity and specificity. These results demonstrate that, as for HIV rapid tests, carefully selected immunodominant

\footnotetext{
* Correspondence: Suman.Laal@nyumc.org

${ }^{1}$ TB Biosciences, 205 Webster Street, Bethlehem, PA, USA

Full list of author information is available at the end of the article
}

epitopes of highly antigenic M. tuberculosis specific proteins can be the basis of antibody detection based rapid POC TB test. Test optimization to improve accuracy to meet WHO specifications for a POC test to replace microscopy or a triage test to rule-out $\mathrm{TB}$ are ongoing.

\section{Authors' details}

${ }^{1}$ TB Biosciences, 205 Webster Street, Bethlehem, PA, USA. ²Lehigh University, Department of Chemistry, Bethlehem, PA, USA. ${ }^{3}$ Veterans Affairs Medical Center, New York Harbor Health Care System, New York, NY, USA. ${ }^{4}$ New York University Langone Medical Center, Departments of Pathology and Microbiology, New York, NY, USA.

Published: 27 May 2014

\section{doi:10.1186/1471-2334-14-S3-E27}

Cite this article as: Gonzalez et al:: M. tuberculosis Peptide based Pointof care test for TB. BMC Infectious Diseases 2014 14(Suppl 3):E27.
Submit your next manuscript to BioMed Central and take full advantage of:

- Convenient online submission

- Thorough peer review

- No space constraints or color figure charges

- Immediate publication on acceptance

- Inclusion in PubMed, CAS, Scopus and Google Scholar

- Research which is freely available for redistribution
() Biomed Central
C Biomed Central

(c) 2014 Gonzalez et al; licensee BioMed Central Ltd. This is an Open Access article distributed under the terms of the Creative Commons Attribution License (http://creativecommons.org/licenses/by/4.0), which permits unrestricted use, distribution, and reproduction in any medium, provided the original work is properly cited. The Creative Commons Public Domain Dedication waiver (http://creativecommons.org/publicdomain/zero/1.0/) applies to the data made available in this article, unless otherwise stated. 